\title{
Prevalence of Candida yeasts in oral samples from children with AIDS and children exposed and not exposed to HIV served by SUS in the state of Bahia, Brazil
}

Prevalência de leveduras do gênero Candida em amostras bucais de crianças com AIDS, expostas e nãoexpostas ao HIV atendidas pelo SUS no interior da Bahia-Brasil

Francine Cristina SILVA ${ }^{1}$

Vivian Oliveira VIANA ${ }^{2}$

Bruno Pereira de ARAÚJO²

Laíze Aparecida Nunes Lopes CAMPOS²

Luciano Pereira ROSA ${ }^{2}$

\section{ABSTRACT}

Objective

This study aimed to determine the prevalence of Candida albicans and non-albicans yeast species isolated from oral samples of children with AIDS and of children exposed and not exposed to HIVduring pregnancy and served by the public health system in a county located in the interior of the state of Bahia, Brazil.

\section{Methods}

Saliva samples from 50 children aged between 2 and 12 years treated by SUS (group I = control group, group II = group exposed to HIV without seroconversion, and group III = AIDS carriers) were collected, seeded in Sabouraud dextrose agar with chloramphenicol, and fungal cultures were grown at $35 \pm 2^{\circ} \mathrm{C}$ for 24 hours. Three isolated colonies were randomly selected from each individual plaque for identification using the API20 AUX Biomerieux ${ }^{\circledR}$ method.

\section{Results}

The most frequent fungal species in samples from children not exposed to HIV, exposed to HIV, and AIDS carriers was Candida albicans $(48.80 \%, 25.64 \%$, and $58.13 \%$, respectively). Species of Candida non-albicans were also isolated from all groups studied.

\section{Conclusions}

Despite the higher prevalence of Candida albicans in these groups, non-albicans species represented a significant percentage of Candida isolates.

Indexing terms: Acquired Immunodeficiency Syndrome. Candida. Child. Prevalence.

\section{RESUMO}

\section{Objetivo}

Verificar a prevalência de leveduras do gênero Candida albicans e não-albicans isoladas de amostras bucais de crianças com AIDS, expostas ao HIV durante o período gestacional e não-expostas ao HIV atendidas pelo sistema único de saúde em um município do interior da Bahia- Brasil.

\section{Métodos}

Para a realização do estudo foram coletadas amostras de saliva de 50 crianças entre 2 e 12 anos atendidas pelo SUS (grupo I = controle; grupo II = expostas ao HIV, sem soroconversão e grupo III = portadoras da AIDS), que após semeadas em ágar Sabouraud dextrose com cloranfenicol, foram incubadas a $35^{\circ} \mathrm{C} \pm 2 / 24 \mathrm{~h}$ para verificação de crescimento de colônias. Dessas foram selecionadas aleatoriamente 3 cepas, de cadá indivíduo, para identificação pelo método API 20 AUX da Biomerieux ${ }^{\circledR}$.

\section{Resultados}

A espécie mais isolada nas amostras coletadas para os grupos de crianças não expostas ao HIV, expostas ao HIV e portadoras da AIDS foi a Candida albicans (48,8\%; $25,64 \%$ e 58,13\% respectivamente). Foram também isoladas espécies de Candida não-albicans em todos os grupos estudados.

\section{Conclusões}

Observou-se que apesar de haver uma prevalência de espécies de Candida albicans isoladas, as espécies não-albicans perfizeram um percentual significativo dos isolados dessa espécie.

Termos de indexação: Candida. Criança. Síndrome da Imunodeficiência adquirida, Prevalência.

\footnotetext{
${ }^{1}$ Universidade Federal da Bahia, Instituto Multidisciplinar em Saúde, Campus Anísio Teixeira. Rua Rio de Contas, 58, Candeias, 45029-094, Vitória da Conquista, BA, Brasil. Correspondência para / Correspondence to: FC SILVA. E-mail: <drfransilva@yahoo.com.br>

${ }^{2}$ Universidade Federal da Bahia, Campus de Vitória da Conquista. Vitória da Conquista, BA, Brasil.
} 


\section{INTRODUCTION}

Although Brazil has one of the best programs to treat human immunodeficiency virus (HIV), in the current decades, the epidemic has shown different characteristics with the feminization of acquired immunodeficiency syndrome (AIDS) that contribute to the increase in vertical transmission. This tendency has been observed throughout Brazil by the increased number of newborns exposed to the risk of HIV ${ }^{1-3}$.

The first cases of AIDS in children were recorded in 1982 by Ammann and O'Reilly, who reported cases of vertical transmission of HIV from the infected mother to child. In Brazil, AIDS cases in pediatric patients were first reported in 1983. Since then, AIDS cases in children have increased considerably in Brazil andworldwide ${ }^{4-6}$.

Most children acquire the virus from their mothers through vertical transmission, which compromises their immune system in the fullness of its growth ${ }^{6}$. Vertical transmission can occur in the uterus at anytime during pregnancy, during normal or cesarean delivery, or via breastfeeding ${ }^{1-3,5}$.

Significant functional abnormalities due to HIV infection make children more susceptible to opportunistic infections, including those in the oral cavity. Previous studies have found that the frequency of children in Brazil and in the United States with oral manifestations associated with HIV infection is high $(72.73 \%$ and $53.66 \%$, respectively). The significant outcomes include erythematous candidiasis and angular cheilitis, which etiologically may be associated with Candida species ${ }^{4-6}$.

Acute pseudomembranous candidiasis occurs most often in oral candidiasis and present clinically as white or yellowishpatches in the underlying oral mucosa. In addition, their removal exposes areas of inflammation area and sometimes results in bleeding and pain, which may impair swallowing. Erythematous candidiasis presents clinically as reddish macules in the palate and back of the tongue, with variable pain and recurrence. Angular cheilitis is characterized by erythematous lesions or fissures in the corners of the mouth with painful symptoms. In cases of severe immunodeficiency, lesions can spread throughout the oral cavity and pharynx and significantly compromise food ingestion and the nutritional status of the individual ${ }^{4,6}$.

All these oral manifestations associated with Candida species in HIV-positive children are related to the opportunistic character of the yeasts. The lesions caused by Candida infection in the oral cavity of these children are due to immunosuppression with the involvement of $C D 4+T$ lymphocytes and increased viral load as disease progresses $^{7-8}$.

Oral candidiasis is strongly indicative of the development of AIDS and may present clinical features of the pseudomembranous or erythematous forms, or their combination thereof ${ }^{4,8-10}$. According to Domaneschi et al. ${ }^{4}$, oral candidiasis is the most frequently observed opportunistic infection in HIV-infected children and its prevalence ranges between $20 \%$ and $72 \%$. In addition, it persists for long periods and is often resistant to conventional antifungal therapies.

According to Martins et al. ${ }^{11}$, the prevalence of mouth candidiasis among healthy children in the United States and Brazil is approximately $30 \%$ and $47 \%$, respectively. However, these rates increase to $48 \%$ in immune compromised children in Africa and $50 \%$ in HIVpositive children in the United States.

Candida albicans is the most prevalent yeast species in the oral cavity of adults and HIV-positive children, and in children with AIDS. The presence of this fungal species in the mouth does not necessarily imply candidiasis but underscores the importance of clinical care to avoid opportunistic infections ${ }^{9-10}$. This species is highly versatile, adapts to different conditions, and finds appropriate conditions for growth in the mucosal tissues of patients with low quality diet, poor oral hygiene, and multiple cavities ${ }^{11-12}$.

Candida non-albicans species that are part of the normal flora of skin and mucocutaneous surfaces are rarely associated with clinical pathologies. Since 1995, there have been reports about emerging pathogenic yeasts and underlying clinical conditions with the isolation of nonalbicans species including Candida parapsilosis, C. glabrata, C. krusei, C. guilliermondii, C. lipolytica, and C.kefyr. Several explanations have been proposed for the sudden emergence of these novel yeast species as infectious agents, including the use of broad-spectrum antibiotics, antineoplastic agents, intravenous catheterization, and the increasing number of patients with neutropenia and immunosuppression ${ }^{4,13-14}$.

Although some studies have reported the presence of Candida species in the oral cavity, data on the prevalence and pathological relationships among these species in the oral cavity of HIV-positive children and children with AIDS are still scarce ${ }^{4,8,13}$. This problem also underscores the need for increased surveillance of children with HIV through preventive oral healthcare programs targeted at reducing 
oral colonization with pathogens that impact the overall health status of vulnerable populations, including HIVpositive children and children with AIDS 7,9 .

Therefore, the aim of this study was to determine the prevalence of Candida albicans and non-albicans yeasts isolated from oral samples of children with AIDS and from children exposed and not exposed to HIV during pregnancy and treated through the public healthcare system in a city located in the interior of Bahia, Brazil.

\section{METHODS}

This study was approved by the Research Ethics Committee of the Bahia State University, campus of Jequié (CAAE0124.0.053.000-08; Opinion No.348/2009).

The study evaluated 50 children treated at a family health unit and at a health care unit specialized in the treatment and monitoring of patients with sexually transmitted diseases, all operated through the National Unified Health System (SUS). Of these children, 20 never had contact with HIV during pregnancy (group I and control group), 15 were exposed to HIV during pregnancy but did not seroconvert at the time of sample collection (group II), and 15 were AIDS carriers (group III). The exclusion criteria were the absence of suspected candidiasis lesions at the time of collection, absence of orthodontic devices and/or other devices that favored the development of Candida infections, absence of use of antibiotics/antifungals in the past three months, and those with uncontrolled chronic diseases. The experiments were conducted using saliva samples collected in sterile disposable universal containers and processed in the microbiology laboratory of the Federal University of Bahia, campus Vitoria da Conquista, state of Bahia, where the study was conducted.

The collected saliva samples were diluted in the ratios 10:1, 10:2, and 10:3 in sterile microtubes containing $900 \mu \mathrm{L}$ of sterile saline. Subsequently, $100 \mu \mathrm{L}$ aliquots were plated in duplicate on Sabouraud Dextrose Agar (Difco, Detroit, USA) supplemented with chloramphenicol (Carlo Erba, $0.1 \mathrm{mg}$ per $\mathrm{mL}$ of medium). These plates were incubated at $35 \pm 2^{\circ} \mathrm{C}$ for 48 hours and at room temperature for 5 days. After incubation, 3 isolated colonies from each plaque were randomly selected, collected, and stored for later identification.

Identifications were performed using the API20C AUX BioMérieux ${ }^{\circledR}$ system for yeast identification. For this purpose, the stored samples were thawed and an aliquot of each isolated colony was grown on Sabouraud dextrose agar (Difco, Detroit, USA) for 24-48 hours, after which the cultures were aseptically transferred to tubes containing 1 $\mathrm{ml}$ of sterile physiological solution $(0.85 \% \mathrm{NaCl})$ adjusted to a turbidity equivalent to a Mc Farland standard of 2 . An aliquot of this suspension was added to the API20C AUX basal medium and homogenized, and subsequently transferred to the wells of the identification panel. This mixture was incubated in a moist chamber at $35 \pm 2^{\circ} \mathrm{C}$, with readings at 24,48 , and 72 hours.

The presence or absence of opacity in the wells for each carbohydrate was considered a positive or negative result, respectively. A seven-digit code was obtained and interpreted using the API20C AUX analytical catalog. Identifications listed in the index as excellent ( $\geq 99.9 \%$ id and $T \geq 0.75$ ), very good ( $\geq 99.0 \%$ id and $T \geq 0.5$ ), and acceptable ( $\geq 90.0 \%$ id and $T \geq 05$ ) were deemed correct, according to the manufacturer's instruction. The identified species were represented as prevalence rates for each study group.

\section{RESULTS}

After sample processing and isolate identification, we defined the percentage of positivity for Candida species (other yeasts species, including Saccharomyces and Trichosporon, were identified but not included in the analysis) as follows: group I $=60$ isolates, of which 52 tested positive for Candida spp.; group II $=45$ isolates, of which 36 tested positive for Candida spp.; and group III = 45 isolates, of which 40 tested positive for Candida spp.

The prevalence of Candida species was represented as percentages in the three groups and these rates are shown in Figure 1.

It was observed that Candida albicans was the most frequent species isolated from the group of children exposed and not exposed to HIV and among children with AIDS $(48.8 \%, 25.64 \%$, and $58.13 \%$ respectively). Candida famata was the second most frequent species among those not exposed to HIV and those with AIDS (24.4\% and $13.9 \%$ respectively) and the third most common species isolated from the group exposed to HIV (20.51\%). Candida parapsilosis was the second most common species in the group exposed to HIV (23.07\%), the third most common in the group not exposed to HIV, and was not found in samples from children with AIDS. Candida tropicalis was isolated from samples of the three groups but its prevalence was small (2.2\% in the group not exposed to HIV, $5.12 \%$ in the group exposed to HIV, and $4.65 \%$ in the group with AIDS) compared with Candida albicans, C.famata, and 
C.parapsilosis. Candida norvegensis, C. kefyr, and C. dubliniensis were identified in a few isolates from the group exposed to HIV (2.56\%). Candida dubliniensis, C. utilis, C. sphaerica, and C. peliculosa were identified in a few isolates from the group with AIDS (6.97\%, 4.65\%, $6.97 \%$, and $2.32 \%$, respectively) whereas Candida utilis was identified in isolates from children not exposed to HIV $(2.2 \%)$.

Our results indicate that, although Candida albicans was the most prevalent species in all groups evaluated, nonalbicans Candida species, when combined, represented a significant percentage among the isolates from these groups.

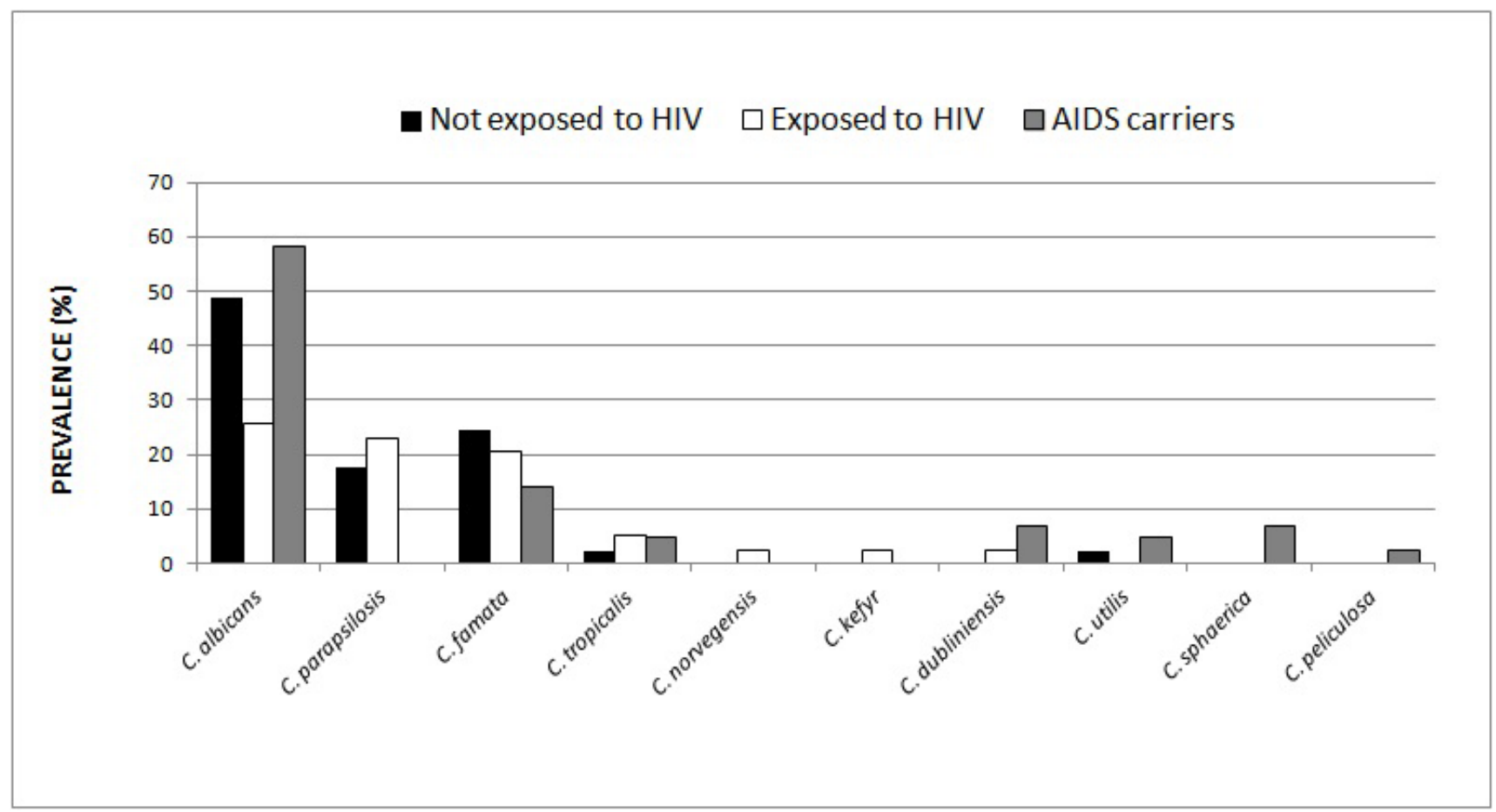

Figure1. Prevalence rates of Candida species isolated from children exposed and not exposed to HIV and from children with AIDS.

\section{DISCUSSION}

Komiyama et al. ${ }^{15}$ reported that the Candida yeasts isolated from the oral cavity of children represent $45 \%$ $65 \%$ of the total fungal isolates and that Candida albicans was the most frequent species in this region, as reported in other studies in the literature ${ }^{4,8-10,14}$. In the present study, a positivity of $30 \%$ was obtained for Candida in the control group and a wide range of Candida species was isolated from children who used inhaled corticosteroids, a condition that predisposes individuals to the development of oral candidiasis ${ }^{15}$.

Martins et al. ${ }^{11}$ showed that the prevalence of yeast species isolated from the oral cavity of healthy children in the United States and Brazil was approximately 30\% and $47 \%$, respectively. However, these rates increased to $48.4 \%$ in immune compromised children in Africa and to $50 \%$ in HIV-positive children in the United States.
The data from the present study corroborate those of Gaitón-Cepeda et al. ${ }^{9}$, Martins et al. ${ }^{11}$, Komiyama et al. ${ }^{15}$, and Cerqueira et al. ${ }^{16}$, who also showed positivity for Candida spp. in children, and Candida albicans was the most prevalent isolate. In addition, a wide range of Candida species was isolated from the oral cavity in three groups of children examined in the present study as well as in the studies of Domaneschi et al. ${ }^{4}$, Gaitón-Cepeda et al. ${ }^{9}$, Komiyama et al. ${ }^{15}$, and Cerqueira et al. ${ }^{16}$.

The study of Komiyama et al..$^{15}$ showed an increased prevalence of Candida non-albicans species isolated from the oral cavity of children predisposed to opportunistic infections and in the control group. Similarly, the present study showed a high prevalence of Candida non-albicans species in the group of children with AIDS - a condition equally favorable to the emergence of opportunistic infections - and in the groups of children without AIDS. The most frequent Candida non-albicans 
species were C. parapsilosis, C. famata, and C. tropicalis, as reported by Macedo et al. ${ }^{17}$.

The main clinically relevant Candida species are Candida albicans, C. parapsilosis, and C. tropicalis. However, an increasing number of cases of superficial and invasive diseases caused by emerging Candida species (species that have appeared recently in a population or whose incidence and geographic range has increased rapidly) have been described and include C. dubliniensis, C. kefyr, C. famata, C. utilis, and C. norvegensis, among others ${ }^{17-18}$. In the present study, the Candida species considered the most important clinically and that are emerging were isolated from the oral cavity of children exposed and non-exposed to HIV and of children with AIDS. The same species were also isolated from HIV-positive and HIV-negative children by Cerqueira et al. ${ }^{16}$. The correct identification of the yeast species has great clinical and epidemiological relevance and indicates the species that are resistant to conventionally antifungal agents used in clinical practice ${ }^{16-19}$.

Similar to the results of this study, Domaneschi et al. ${ }^{4}$ and Cerqueira et al. ${ }^{16}$ identified Candida tropicalis, C. kefyr, C. krusei, and C. glabrata isolates from the oral cavity of HIV-positive children and children with AIDS treated at a hospital in São Paulo. Only Candida guilliermondii was isolated differently in the study of Domaneschi et al. ${ }^{4}$ in connection with this study, in turn, isolated from other Candida species.

The study of Gaitón-Cepeda et al. ${ }^{9}$ indicated a high frequency of Candida non-albicans species isolated from the oral cavity of HIV-positive children and children with AIDS associated with malnutrition, and C. krusei was the most prevalent non-albicans species. Similarly, the present study identified several non-albicans species in children with AIDS. However, unlike the study of Gaitón-Cepeda et al. ${ }^{9}$, the most prevalent non-albicans species in this group was Candida famata.

According to Gaitón-Cepeda et al. ${ }^{9}$ and Christopher et al. ${ }^{16}$, the increased prevalence of Candida non-albicans isolates in the oral cavity is important because it increases the susceptibility to oral candidiasis that is refractory to the antifungal agents used routinely. Mujica et al. ${ }^{14}$ reported that the incorporation of fluconazole in antifungal therapy can select strains that

\section{REFERENCES}

1. Galvão MTG, Cunha GH, Machado MMT. Dilemas e conflitos de ser mãe na vigência do HIVIAIDS. Rev Bras Enferm. 2010;63(3):371-6. doi:10.1590/S0034-71672010000300004. are resistant to this antifungal agent and can affect the prevalence of Candida species in the oral cavity of HIVinfected individuals and those with AIDS.

However, despite the higher prevalence of Candida albicans species in the patient groups studied, the non-albicans species amounted to a high percentage of Candida isolates and were associated with worse prognosis in cases of candidemias ${ }^{19}$.

According to Gaitón-Cepeda et al. ${ }^{9}$, preventive oral healthcare programs aimed at reducing the colonization with Candida species in the oral cavity of HIV-positive children and children with AIDS are essential because candidiasis due to these species has an impact on the general health of this vulnerable population.

Epidemiological studies aimed at evaluating the profile of Candida species colonizing the oral cavity of HIV-positive children and children with AIDS are important because, according to Sanchez-Vargas et al. ${ }^{10}$, there is limited knowledge of the etiological importance of the different yeast species that colonize the oral cavity and cause infections in such patients.

Therefore, the results of this study are important because the knowledge of Candida species favors the use of appropriate antifungal therapies and enables the development of further research focused on novel treatments considering the peculiarity of each fungal species.

\section{CONCLUSION}

We isolated a wide range of Candida species from the oral cavity of children exposed and not exposed to HIV and of children with AIDS. Candida albicans was the most prevalent Candida species in these three groups and Candida non-albicans species, when combined, amounted to a significant percentage of Candida isolates.

\section{Acknowledgements}

We are grateful to the Bahia State Research Support Foundation (FAPESB) for research funding (PPSUS call for proposals; grant SUS0039/2009) and to the patients and parents who enrolled in the study.

2. Lemos LMD, Rocha TFS, Conceição MV, Silva EL, Santos AHS, Gurgel RQ. Evalution of preventive measures for mother-tochild transmission of HIV in Aracaju, State of Sergipe, Brasil. Rev Soc Bras Med Trop. 2012;45(6):682-6. doi:10.1590/ S0213 $-86822012000600005$ 
3. Olugbenga-Bello A, Adebimpe WO, Osundina FF, Abdulsalam ST. Perception on prevention of mother-to-child-transmission (PMTCT) of HIV among women of reproductive age group in Osogbo, Southwestern Nigeria. Int J of Women's Health. 2013;5:399-405. doi:10.2147/IJWH.S45815

4. Domaneschi C, Massarente, DB, Freitas RS, Souza Marques $H H$, Paula $C R$, Migliari $C R$, et al. Oral colonization by Candida species in AIDS pediatric patients. Oral Dis. 2011;17(4):393-8. doi:10.1111/j.1601-0825.2010.01765.x

5. Grando LJ, Yurgel LS, Machado DC, Silva CL, Menezes M, Picolli C. Manifestações estomatológicas, contagem de LTCD4+ e carga viral de crianças brasileiras e norte-americanas infectadas pelo HIV. Pesqui Odontol Bras. 2002;16(1):18-25. doi:10.1590/ S1517-74912002000100004

6. Grando LJ, Yurgel LS, Machado DC, Nachman S, Ferguson $\mathrm{F}$, Berentsen $\mathrm{B}$, et al. Associação entre manifestações estomatológicas e características socioeconômicas e culturais de crianças brasileiras e norte-americanas infectadas pelo HIV. Rev Panam Salud Públ. 2003;14(2):112-18. doi:10.1590/S102049892003000700006

7. Campos JADB, Loffredo LCM. Reprodutilidade de uma escala odontológica proposta como indicador de saúde bucal em crianças e adolescentes HIV+/SIDA. Cienc Saúde Coletiva. 2010;15(4):2181-7. doi:10.1590/S1413-81232010000400032

8. Pomarico L, Cerqueira DF, Soares RMA, Souza IPR, Castro GFBA, Socransky $S$, et al. Associations among the use of highly active antiretroviral therapy, oral candidiasis, oral Candida species and salivary immunoglobulin A in HIV-infected children. Oral Surg Oral Med Oral Pathol Oral RadiolEndod. 2009;108(2):203-10. doi:10.1016/j.tripleo.2009.05.008

9. Gaitón-Cepeda LA, Sánchez-Vargas LO, Pavia-Ruz N, MuñozHernández R, Villegas-Ham J, Caballos-Salobreña A. Candida bucal em niños mexicanos com VIH/SIDA, desnutrición o marginación social. Rev Panam Salud Públ. 2012;31(1):48-53. doi:10.1590/S1020-49892012000100007

10. Sánchez-Vargas LO, Ortiz-López G, Villar M, Moragues MD, Aguirre JM, Cashat-Cruz M, et al. Point prevalence, microbiology e antifungal susceptibility patterns of oral Candida isolates colonizing or infection Mexicans HIV/AIDS patients and healthy persons. Rev Iberoam Micol. 2005;22(2):83-92.

11. Martins ACM, Maluf MLF, Svidzunski TIE. Prevalence of yeast species in the oral cavity and its relationship to dental caries. Acta
Scientarium Helth Sciences. 2011;33(1):107-12. doi:10.4025/ actascihealthsci.v33i1.7712

12. Roselló YC, Foster TH, Nazario NP, Miltra S, Haidaris CG. Sensivity of Candida albicans germ tubes and biofilms to photofrin-mediated phototoxicity. Antimicro Agent Chemo. 2005;49(10):4288-4295. doi:10.1128/AAC.49.10.4288-4295.2005

13. Diz DP, Ocampo A, Otero I, Iglesias I, Martínez C. Changes in oropharyngeal colonization and infection by Candida albicans in Human immunodeficiency virus-infected patients. J Inf Dis. 2001;1839(4):355-56. doi:10.1086/317920

14. Mujica MT, Finquelevich $\mathrm{JL}$, Jewtuchowicz $\mathrm{V}$, lovannitti $C A$. Prevalência de Candida albicans y Candida no albicans en diferentes muestras clínicas: periodo 1999-2001. Rev Argent Microbiol. 2004;36(3):107-12.

15. Komiyama EY, Ribeiro PM, Junqueira JC, Koga-Ito $C Y$, Jorge AOC. Prevalence of yeasts in the oral cavity of children treated with inhaled corticosteroids. Braz Oral Res. 2004;18(3):197-201. doi:10.1590/S1806-83242004000300004

16. Cerqueira DF, Portela MB, Pomarico L, de AraújoSoares RM, de Souza IP, Castro GF. Oral Candida colonization and its relation with predisposing factors in HIV-infected children and their uninfected siblings in Brazil: the era of highly active antiretroviral therapy. J Oral Pathol Med. 2010;39(2):188-94. doi:10.1111/ j.1600-0714.2009.00857.x

17. Macêdo DPC,Farias AMA, Neto RGL, Silva VKA da, Leal AFG, Neves RP. Infecções oportunistas por leveduras e perfilenzimático dos agentes etiológicos. Rev Soc Bras Med Trop. 2009;42(2):18891. doi:10.1590/S0037-86822009000200019

18. Colombo AL, Guimarães, T. Epidemiologia das Infecções hematogenicas por Candida spp. Rev Soc Bras Med Trop. 2003;36(5):599-607. doi:10.1590/S0037-86822003000500010

19. Rörig KCO, Colacite J, Abegg MA. Produção de fatores de virulência in vitro por espécies patogênicas do gênero Candida. Rev Soc Bras Med Trop. 2009;42(2):225-7. doi:10.1590/S003786822009000200029 